\title{
O significado do lulismo na vida política brasileira: direitos e institucionalização das lutas à luz da Constituição de 88
}

Josué Medeiros

\author{
Josué Medeiros \\ Professor Adjunto do Departamento de Ciência Política da \\ Universidade Federal do Rio de Janeiro. \\ Email: josuedsrj@gmail.com \\ Lattes: http://lattes.cnpq.br/4911372151960584 \\ ORCID: https://orcid.org/0000-0002-6421-9170
}

\begin{abstract}
Resumo:
O objetivo do artigo é analisar a crise da democracia brasileira a partir das relações entre o fenômeno político do Iulismo e a Constituição de 1988. Nossa hipótese é que o lulismo, para além da um realinhamento eleitoral, é herdeiro de um conjunto de lutas por direitos que atravessam a Carta Constitucional e das dinâmicas de institucionalização desses direitos. Chamamos esse conjunto de lutas de petismo e argumentamos que o lulismo foi um dos seus resultados possíveis. Nesse sentido, a presente crise da democracia se viabilizou com dois eventos - o golpe parlamentar de 2016 e a prisão de Lula em 2018 - que, juntos, serviram para interditar o /ulismo da disputa política, alterando radicalmente o padrão de competição eleitoral vigente desde 1989. Desenvolvemos o argumento de que essa interdição tem um sentido para além do desiquilíbrio das eleições: a coalizão que assumiu o poder em 2016 e depois ajudou a eleger e sustentar o bolsonarismo necessita cancelar a própria relação entre lutas e direitos que desaguaram no lulismo de modo a anular as dimensões democráticas da Constituição de 88 e instaurar a hegemonia do neoliberalismo antidemocrático no Brasil.
\end{abstract}

\section{Palavras-chaves:}

Democracia; neoliberalismo; lulismo.

\begin{abstract}
:
The objective of the article is to analyze the crisis of Brazilian democracy from the relation between the political phenomenon of Lulismo and the 1988 Constitution. Our hypothesis is that Lulismo, in addition to electoral realignment, is heir to a set of struggles for rights that cross the Constitutional Charter and the dynamics of institutionalizing these rights. This set of struggles, we call petismo and we argue that Lulismo was one of its possible results. In this sense, the present crisis of democracy was made possible with two events - the 2016 parliamentary coup and Lula's arrest in 2018 - which, together, served to interdict the Lulismo of the political dispute, radically altering the pattern of electoral competition in force since 1989. We developed the argument that this interdiction has a meaning beyond the imbalance of the elections: the coalition that took power in 2016 and then helped to elect and sustain bolsonarism needs to cancel the very relation between struggles and rights that
\end{abstract}


flowed into Lulismo in order to annul the democratic dimensions of the Constitution of 88 and establish the hegemony of anti-democratic neoliberalism in Brazil.

Keywords: Democracy; neoliberalism; lulismo

\section{Introdução}

O presente artigo analisa a política brasileira com problematizando a categoria de crise da democracia, termo usado no debate público e acadêmico - brasileiro e internacional - para explicar a atual força da extrema-direita desde a vitória de Donald Trump em 2016 nos EUA. No Brasil, tal crise se inicia com o golpe parlamentar (Santos: 2017) contra Dilma Rousseff e é reforçada pelo assassinato da vereadora Marielle Franco, pela prisão de Lula e pela eleição de Jair Bolsonaro em 2018. Entretanto, tal noção apresenta dois problemas: é demasiado vaga e sem condições de explicar o que anuncia; e se liga estruturalmente à concepção liberal de democracia. Nesta interpretação (Müller, 2016; Levitsky e Ziblatt, 2019; Mounk, 2018; Runcimann, 2018; Przeworski, 2020), as democracias liberais são corroídas por dentro, em processos que usam as regras e procedimentos da democracia contra as instituições democráticas. O remédio contra isso é o reforço das próprias instituições corroídas.

É preciso então cotejar o uso dessa categoria com a necessidade de adaptar os modelos estrangeiros à realidade interna da nação, tal como propõe Roberto Schwarz:

Nos países saídos da colonização, o conjunto de categorias históricas plasmadas pela experiência intra-européia passa a funcionar num espaço com travejamento sociológico diferente, diverso, mas não alheio, em que aquelas categorias nem se aplicam com propriedade, nem podem deixar de se aplicar. Um espaço diverso, porque a colonização não criava sociedades semelhantes à metrópole, nem a ulterior divisão internacional do trabalho igualava as nações. Mas um espaço de mesma ordem, porque também ele é comandado pela dinâmica abrangente do capital (1999:9-10).

Trata-se, portanto, de "uma meia vigência das coordenadas europeias (...) o que requer malícia diferencial por parte do observador" uma vez que a "aplicação de categorias sociais europeias (...) ao Brasil e às demais ex-colônias" é "um procedimento que leva ao equívoco, ao mesmo tempo que é inevitável e indispensável" (Idem).

O modo como isso será feito nesse texto é analisar a crise da democracia brasileira a partir do fenômeno político do lulismo, da sua relação com a Constituição de 1988 e do que chamamos de petismo (Medeiros: 2016) nesse processo. Primeiro recuperamos parte do debate sobre a Constituição e democracia brasileira; segundo, apresentamos uma definição do lulismo e do petismo; terceiro, examinamos a influência das lutas sociais da década de 1980 na constituinte e como o PT atuou naquela conjuntura; quarto, analisamos o enraizamento da Constituição em meio à hegemonia neoliberal; por fim, chegamos ao governo Lula em si, analisando o lulismo na política brasileira. Nas considerações finais, nos apoiamos em Wendy Brown para compreender o tipo de neoliberalismo antidemocrático que hoje governa a nossa democracia em crise. 
Josué Medeiros

\title{
Preparando o terreno: a Constituição e a democracia
}

A noção de que a Constituição de 1988 é o marco fundamental de um processo de consolidação democrática no Brasil é amplamente aceita nas ciências humanas. 0 resumo feito por José Murilo de Carvalho, em 2001, é ilustrativo:

\begin{abstract}
Apesar da tragédia da morte de Tancredo Neves, a retomada da supremacia civil em 1985 se fez de maneira razoavelmente ordenada e, até agora, sem retrocessos. A constituinte de 1988 redigiu e aprovou a constituição mais liberal e democrática que o país já teve, merecendo por isso o nome de Constituição Cidadã. Em 1989, houve a primeira eleição direta para presidente desde 1960 . Os direitos políticos adquiriram amplitude nunca antes estabelecida. (2001: 199. Grifo meu.)
\end{abstract}

O destaque no "até agora" é necessário nesses tempos de ataques dos mais variados tipos à democracia brasileira e à Constituição. Voltaremos a isso mais adiante.

A institucionalidade consolidada pela Carta de 88 resolveu o que, para Wanderley Guilherme dos Santos, foi "desde a Independência o problema teórico e prático das elites políticas e intelectuais brasileiras", a saber, "de que modo implantar e garantir um eficiente funcionamento da ordem liberal burguesa" (2002:57), o que não ocorreria com o autoritarismo político. E tampouco poderia ser feito sem elementos contraditórios, justamente pela dimensão periférica do Brasil apontada por Schwarz (1999).

Para o crítico literário, o lugar específico de ex-colônia e de periferia de um sistema global nos exige relativizar as "as polarizações abstratas" tais como "escravidão e liberdade", e também a "identificação ideológica entre liberdade e capitalismo" em favor "dos paradoxos do movimento histórico". É necessário se despir das "ilusões de uma concepção linear do progresso" uma vez que entendemos que "o progresso nacional repõe, isto é, reproduz e até amplia as inaceitáveis relações sociais da Colônia". Schwarz afirma que nossa formação social encerra formalmente a escravidão não

para integrar o negro como cidadão à sociedade livre, mas para enredá-lo em formas velhas e novas de inferioridade, sujeição pessoal e pobreza, nas quais se reproduzem outros aspectos da herança colonial, que teima em não se dissolver e parece continuar com um grande futuro pela frente, o qual é preciso reconhecer, ainda uma vez, como fundado na evolução moderna da economia (1999: 8)

Assim, trata-se de entender que "a história (...) procede por avanços e recuos combinados" e que, não obstante, "ela avança", e Schwarz nos lembra "tanto que o capitalismo acaba obrigando à Abolição" (1999: 9) ou, para os fins deste artigo, que o capitalismo "acaba obrigando" ao fim da ditadura. Nota-se mais uma vez que, em meio a uma concepção de história dialética e aberta, as lutas que foram fundamentais para o fim da escravidão formal (ou para o fim do autoritarismo) ficam subsumidas às categorias universais "capitalismo" e "história", com todos os problemas decorrentes disso. Ainda assim, seguimos Schwarz na compreensão desse movimento no qual a história "ao avançar, ela não cumpre as promessas formadas no âmbito do conflito anterior" o que gera uma contradição sem solução pois "chegado o momento, o avanço tem a realidade de uma tarefa iniludível, em cujo cumprimento, contudo há espaço para uma certa liberdade e invenção políticas, bem como para o surgimento de desumanidades novas" (Idem). Aqui a história se abre de novo, mais sem "a ingenuidade dos progressismos corrente", pois o fato é que há 
Josué Medeiros

"as regressões, de que se compõe o progresso" o que leva o autor a perguntar: "aliás, progresso de quem?" (Idem).

A Constituição de 1988 é, portanto, progresso e regressão para os de baixo e, ao mesmo tempo, o marco de abertura de um novo processo histórico-político. Heloísa Starling e Lilian Schwarcz (2015), em sua biografia do Brasil, destacam tanto a consolidação democrática pela chave dos direitos quanto as permanências do passado:

Como o Brasil e como a própria democracia, a Constituição também é imperfeita. Envolveu movimentos contraditórios e embates formidáveis entre forças políticas desiguais, e inúmeras vezes errou de alvo. Conservou intocada a estrutura agrária, permitiu autonomia das Forças Armadas para definir assuntos de seu interesse, derrubou a proposta de jornada de trabalho de 40 horas, manteve inelegíveis os analfabetos - embora tenha aprovado seu direito de voto (...). Mas a Constituição de 1988 é a melhor expressão de que o Brasil tinha um olho no passado e outro no futuro e estava firmando um sólido compromisso democrático. Foi assinada por todos os partidos inclusive o PT. A Constituição de 1988 deu início a um período consistente e duradouro e de vigência das liberdades públicas e de solidez das instituições democráticas. Desde então, todas as eleições presidenciais foram vencidas nas urnas, nenhum mandato foi interrompido e nenhuma vitória eleitoral foi contestada (grifo meu). (2015:489).

Novamente foi necessário sublinhar a citação, desta vez devido a um erro factual das autoras, uma vez que Aécio Neves, do PSDB, contestou o resultado das eleições de 2014 assim que soube da reeleição de Dilma Rousseff, abrindo as portas para a atual conjuntura antidemocrática. Também este ponto voltará mais a frente.

É preciso ainda reforçar a dimensão contraditória da Constituição e da ordem política que dela deriva. Luiz Werneck Vianna mobiliza, em 1996, o conceito gramsciano de "revolução passiva" (no qual a hegemonia burguesa se efetiva conservando elementos do passado e não em ruptura com eles, como nas revoluções burguesas) em dupla chave: primeiro, pela substituição dos militares por "por uma coalizão de forças cada vez mais orientada por valores de mercado e pelo projeto de 'normalização' da ordem burguesa no país" o que levaria à "subordinação de todas as dimensões do social a uma racionalidade derivada das exigências de modernização capitalista" (1997:53); segundo, "porque o seu 'fermento' não está mais no liberalismo nem na questão social", mas na própria "democracia". Desta forma, "a promulgação da Carta de 1988, de abrangência inédita na história do país, eliminou, ao menos em tese, obstáculos institucionais e constitucionais que viessem a interditar" (Idem) a chegada dos subalternos à direção política da república.

Florestan Fernandes, em 1988, no calor da experiência de constituinte pelo PT, analisou estas contradições de um modo mais crítico que Werneck Vianna:

A Constituição de 1988 vem à luz com data marcada para uma revisão global (...). Sufocada pelo poder do dinheiro, tisnada por uma hegemonia de classe, que sequer se deteve diante da mercantilização do voto; oprimida pelo arbítrio de uma 'Nova República', que prolonga a ditadura; vergada pela corrupção, manejada pelo governo e pelo grande capital nacional e estrangeiro; incapaz de sustentar-se sobre um poder originário e soberano; ela veio para durar pouco e servir de elo ao aparecimento de uma constituição mais democrática, 
popular e radical. Sua principal missão consiste em limpar o terreno minado pela ditadura, prepara-lo para outro plantio, mais generoso e fértil (...). A Constituição (...) não se afirma como uma peça homogeneamente conservadora, obscurantista ou reacionária. Ao revés, abre múltiplos caminhos que conferem peso e voz ao trabalhador na sociedade civil (2014: 288-289)

As interpretações das ciências sociais sobre a Constituição de 1988, quer feitas na emoção do parto ou elaboradas ao longo das várias fases da maturação da Carta, buscaram sempre enfrentar os impasses e conflitos que se organizaram em torno dos sentidos da nova ordem democrática e burguesa. Assim, foram muitos os alertas quanto aos riscos de crise sistêmica desta nova ordem e que, se não previram o atual contexto de regressão democrática (e nem deveriam fazê-lo), nos fornecem elementos para compreender o que estamos vivendo hoje. Ainda em 2001, Carvalho afirmava que "a estabilidade democrática não pode ainda ser considerada fora de perigo". A democracia não resolveu segundo o autor, os problemas econômicos, sociais e o problema da segurança. E, "finalmente, as rápidas transformações da economia internacional contribuíram para pôr em xeque a própria concepção tradicional de direitos" (2001: 199).

Tais transformações se condensam na hegemonia neoliberal no mundo e no Brasil. Seus defensores não esperaram muito para tentar a "revisão global" de que falava Florestan, obviamente que em sentido oposto ao dele. Em 1993, iniciou-se um processo de revisão constitucional no Congresso, com vistas a "adaptar" a Carta de 88 à nova situação internacional. Seus defensores afirmavam que esta adaptação estava de acordo com a vontade do constituinte quanto este estabeleceu um prazo de cinco anos após a promulgação da Constituição para um processo desse tipo. Já setores antineoliberais alegavam que a revisão não autorizava uma radical mexida no espírito cidadão da Carta.

Fábio Wanderley Reis analisa este conflito como resultante da tensão "eficiênciademocracia" (2003: 17), na qual o governo Fernando Henrique Cardoso (FHC) defendeu a revisão em prol da eficiência e a oposição contestou as mudanças em nome da democracia. Trata-se do "contraste" entre os sentidos da Assembleia Constituinte, cujo "o problema tem o caráter "clássico" e "constitucional": o objetivo é restaurar a democracia e os objetivos "da revisão constitucional de 1993-4" e das reformas de FHC que visam "aggiornamento da máquina estatal e do país perante as novas tendências do capitalismo mundial, e a preocupação crucial é claramente a de eficiência (2003: 15).

Reis defende que um equilíbrio entre os dois polos deveria ser buscado, pois se, como alegava a oposição, a preocupação com a eficiência acaba reduzindo o "problema político-administrativo" a uma questão técnica, por outro lado, a democracia precisa enfrentar o "desafio da eficiência" para ser assegurada (2003:17). Ocorre que a hegemonia neoliberal inviabiliza qualquer mediação diante do império da técnica. O resultado desta primazia tecnocrática é esvaziar a institucionalidade democrática de sentido, o que favorece os riscos contra a ordem constitucional, sobretudo nos países periféricos onde a democracia não resolve no curto prazo os problemas sociais.

Essa dimensão da imposição da técnica foi definida por Chico de Oliveira como "totalitarismo neoliberal", o qual decorre da "privatização do público" somada à "destituição da fala" dos subalternos, resultando na "anulação da política" (2000:55) e, pior, na própria "destruição" (2000: 79) da classe trabalhadora. Esta destruição também ocorreu na dimensão social, com reorganização do tecido produtivo e o desfazimento do tecido associativo dos trabalhadores na década de 1990, chamada de "a década neoliberal" por Adalberto Cardoso: "despolitização da economia" e a restruturação produtiva resultaram em 
um sindicalismo incapaz de "oferecer alternativas políticas" (2003: 75. Grifo do autor) diferente do que ocorrera nos anos 1980. O neoliberalismo e as dimensões social e política serão importantes quando analisarmos a institucionalização dos direitos.

Por ora é importante fechar essa parte concluindo que embora os sentidos da revisão de 1993 apontassem para uma dinâmica neoliberal nova, aquele processo não se configurou como uma ruptura do pacto constitucional, tal qual a que vivenciamos a partir de 2015 , com a mobilização pelo impeachment de Dilma. Tanto que o petismo pôde seguir sua marcha rumo à conquista do governo e, na sequência, o lulismo teve a chance de responder ao tema da eficiência a partir de uma prioridade ética do social e não da técnica neoliberal, ainda que compondo com importantes elementos neoliberais, em um processo cheio de contradições das quais emerge a própria controvérsia na definição do lulismo.

\section{Definindo o terreno: lulismo e petismo}

É possível organizar a controvérsia política e intelectual em torno do lulismo em três tipos de interpretação: o que define o fenômeno como pós-neoliberal; outro que o entende como continuidade do neoliberalismo; e um último, que denominamos crítico, e que busca analisá-lo em sua integridade contraditória e em seus sentidos gerais.

O campo pós-neoliberal tem como principal obra o livro Brasil: de Getúlio a Lula, uma coletânea de 2010 organizada por Emir Sader e que busca abarcar todas as dimensões da gestão do ex-presidente. Na introdução, Sader exalta o governo em suas realizações mais diversas, com ênfase principal na figura do presidente, que passa a ser comparado com Getúlio Vargas, figura política mais importante da nossa história até Lula.

A hipótese do lulismo e a continuidade do neoliberalismo se baseia no paradigma do populismo, pelo qual cabe à liderança carismática manipular a classe para impedir que ela supere a condição de dominação. Ricardo Antunes afirma em 2006 que Lula traiu os "verdadeiros" interesses da classe trabalhadora (2006: 37). O mesmo autor reforça o ponto em 2011 ao dizer, sem hesitar, que "o mais importante partido de classe das últimas décadas exauriu-se como partido de esquerda transformador da ordem" (2011: 132).

Identificamos uma renovação nos estudos destes dois campos após o golpe de 2016. $\mathrm{Na}$ visão pós-neoliberal, a ruptura institucional aparece como confirmação da tese, como ocorre na obra recente de Jessé Souza (2015; 2016). Já o debate sobre o caráter neoliberal do lulismo perdeu centralidade nos intelectuais deste campo diante da necessidade de enfrentar as consequências do golpe e do bolsonarismo, embora vez ou outra apareça algum tipo de "culpabilização" do PT e de Lula pelo quadro atual.

No terceiro campo interpretativo existem duas dimensões analíticas. Primeiro, as pesquisas com foco na dinâmica eleitoral: Samuels (2004; 2008); Hunter e Power (2007), Zucco (2008); Zucco e Power (2013); Samuels e Zucco (2014). Trata-se de comparar o eleitor histórico do PT com aquele que passou a votar em Lula já na presidência para mapear convergências e diferenças entre os novos eleitores identificados diretamente com o ex-presidente e aqueles que tradicionalmente se vinculavam ao partido.

A segunda é o que busca inserir o lulismo em um conjunto mais amplo de interpretações do Brasil e das relações entre democracia e capitalismo no país. Nesse caso, nosso diálogo se dará principalmente com o cientista político André Singer em os Sentidos de Lulismo (2012), As contradições do Lulismo (2016) e o Lulismo em Crise (2018) Analisaremos esse percurso de Singer na última parte do artigo. 
Nossa contribuição nesse diálogo se dá com a categoria de petismo (Medeiros: 2016): propomos entender a coletividade de movimentos, ativistas e organizações que convergiu para a criação do PT para além das estruturas partidárias, mas como um sujeito político coletivo com grande diversidade interna e com muita capacidade de unidade política. Dentro desta comunidade petista, o lulismo foi uma das construções possíveis que se desenvolveram. Assim, o lulismo não é somente o resultado do realinhamento eleitoral de 2006 (Singer: 2012). É isso também, porém é uma construção anterior às eleições de Lula e que sequer era a única alternativa posta para o petismo em sua história. Tampouco o lulismo resulta somente do líder carismático que "manipula o povo" e "trai a classe" tal como argumenta o paradigma populista. O papel de Lula, embora decisivo, deve ser inserido na rica e tensa relação entre a sua liderança e os vários processos coletivos das classes trabalhadoras nos últimos 40 anos.

A diferenciação entre líder carismático, partido político e a coletividade que os envolve e que eles (figura pública e aparato burocrático) organizam e representam foi tematizada por Gildo Marçal Brandão no caso de Prestes e Partido Comunista Brasileiro (PCB). Brandão é autor de uma ampla pesquisa sobre os sentidos do PCB desde sua fundação até 1964, quando o golpe encerra um longo período de influência do "partidão" na vida política e social brasileira. Ele denomina essa construção de esquerda positiva (Brandão: 1997) por entender que o comunismo no Brasil afirmou um projeto próprio de país e de sociedade nesse período. Quando o autoritarismo militar é derrotado, o PCB, em crise assim como o movimento internacional ao qual era filiado, não consegue recuperar sua base social e dá lugar ao PT como principal articulador das lutas e projetos dos subalternos.

Brandão nos ajuda a refletir sobre a relação entre líderes, partidos e coletividade a partir do exame sobre o fenômeno político que se organizou em torno de Luiz Carlos Prestes, líder tenentista dos anos 1920 e principal dirigente comunista entre os anos 1930 e 1980. Há, de partida, uma semelhança, pois o prestismo "não foi uma doutrina política". (2010: 165), algo que também o lulismo nunca se propôs. Intelectualmente

o "prestismo" não ganhou existência, não chegou a constituir um corpo de ideias e propostas minimamente autônomo e independente das vicissitudes e variações táticas do partido e do movimento internacional ao que ligou sua trajetória e destino (2010:165).

Não há no lulismo um corpo de ideais próprio e deslocado do PT. Entendemos isso como uma virtude quando comparamos com o prestismo tal qual Brandão o define: "um movimento de massas em torno de uma liderança carismática e caudilhesca, em seguida acoplada a um partido semimilitarizado" (Idem). Já a relação entre PT e Lula é orgânica desde o nascimento do partido em 1980, e é impossível entender o desenvolvimento da figura do ex-presidente sem compreender os processos coletivos do petismo. Há sim carisma, mas não há nada próximo de um processo "caudilhesco".

Não obstante, Brandão afirma uma dimensão positiva da relação entre prestismo e comunismo, diferente da teoria populista que enquadra a adesão de Prestes ao PC como "ação desagregadora da pequena burguesia sobre uma esquerda débil, mas operária, circunstância nefasta que estaria na raiz da subalternidade do proletariado à burguesia e ao Estado" (2010: 166). Para ele, em vez de afirmar "Prestes como demiurgo, responsável por quase todos os erros e acertos da esquerda" (Idem) é preciso pensá-lo como a figura "responsável pela nacionalização da esquerda", por tornar o comunismo no Brasil "mais brasileiro, menos europeu" (2010: 166-167). Para Brandão, além da liderança de Prestes ter dependido profundamente da estrutura partidária do $\mathrm{PCB}$, a relação nunca foi de mão única. Por exemplo, a aliança do "partidão" com Vargas em 1945 foi protagonizada por Prestes; já 
o realinhamento em prol da democracia em 1958 foi feito a despeito do principal líder, que só aderiu quando a política já era majoritária no partido (2010: 167).

No mesmo sentido, a liderança de Lula dependeu tanto da força do partido quanto este se fortaleceu a medida em que Lula crescia. E o mais importante é que não haveria nem PT nem Lula sem a potência de vários movimentos e lutas: sindicalismo em especial, mas também lutas urbanas, lutas agrárias, enfrentamento das situações de miséria tanto quanto dos problemas das classes médias ávidas por democracia. A capacidade de Lula em protagonizar processos decisivos (Diretas Já, Constituinte, eleições de 1989, impeachment de Collor, Caravanas da Cidadania, as eleições presidenciais dos anos 1990) não pode ser pensada sem os momentos de luta coletiva impulsionadas por sindicatos (greves gerais dos anos 1980) e movimentos (ocupações de terra do MST nos anos 1990) e por outros dirigentes petistas nas administrações municipais que o PT foi conquistando de $1982 \mathrm{em}$ diante. Em suma, que foram constituídas pelo petismo em sua diversidade.

E é para dar conta dessa diversidade coletiva que é o petismo e dos modos como essa coletividade diversa se relacionou com a democracia e com a Constituição de 1988 que precisamos analisar as décadas de 1980 e 1990 antes de adentar do exame do lulismo como fenômeno político. Os anos 1980 importam pelo modo como as lutas sociais protagonizadas pelo petismo (entre outras forças de esquerda e democráticas) influenciaram a Constituinte; já os anos 1990 são vitais para a compreensão de como os direitos da Constituição de 1988 buscaram se enraizar em meio à hegemonia neoliberal.

\section{A Constituição de 1988 e o terreno aberto das lutas sociais}

É fundamental inserir as lutas sociais nas interpretações do Brasil de um modo geral e, mais especificamente, as lutas sociais dos anos 1980 para entender plenamente os sentidos da Constituição de 1988. Trata-se de elevar as lutas à mesma importância estrutural e analítica das categorias clássicas do pensamento político, tais como o Estado, o desenvolvimento do capitalismo, o papel do latifúndio e da escravidão, entre outros. Nesse sentido, seguimos os passos de diversas pesquisas que já operam dessa maneira, tais como a interpretação do movimento abolicionista como um movimento social proposta por Ângela Alonso (2014), por exemplo.

E também buscamos recuperar um debate travado no âmbito do petismo nos anos 1980. Em um seminário chamado "as esquerdas e a democracia", Carlos Nelson Coutinho chamou atenção para o problema da minimização das lutas nas reconstruções dos processos políticos nacionais entre os estudiosos marxistas. Ele questiona se os próprios intelectuais de esquerda não estariam "reduzindo um pouco a participação popular ao tipo de participação popular que nós queremos, ou seja, organizada, de baixo para cima, partido, sindicato?" (1986: 49). E, conclui ele, que existem "outras formas de pressão popular. E justamente essa pressão popular desorganizada é que leva ao tipo de transição 'pelo alto'. Se fosse organizada, levaria à transição democrática" (1986: 50). Marco Aurélio Garcia, no mesmo debate, conclui que "as revoluções por cima se dão não pela debilidade da classe trabalhadora, mas ao contrário, contra sua força e potência" (1986: 45). Coutinho e Garcia apresentam a noção de "transição pelo alto" ou de "revoluções por cima" para explicar os processos sociais e históricos brasileiros, na mesma chave da "revolução passiva" desenvolvida por Werneck Vianna. Em Coutinho, contudo, o papel das lutas ganha centralidade: 0 autor lê a história do Brasil como um processo de sucessivas revoluções passivas que combatem as lutas sociais. (199: 211-219). 
Isso nos leva a resgatar os ciclos de luta da nossa história, com seus múltiplos sentidos e desfechos. O objetivo é destacar a especificidade do ciclo de lutas da redemocratização como o único que resultou em uma institucionalidade democrática plena. O historiador Alexandre Fortes faz esse registro quando afirma que:

O ciclo de lutas sociais dos anos 1970 e 1980 , ao contrário de outros tão significativos (1917-1919; 1928-1929; 1933-1935; 1945-1947; 1953-1957; 1961-1964; 1968-1969, para ficar apenas no século XX) teve a felicidade de contribuir para mudar profundamente a relação da nossa sociedade com a político, gerando o movimento mais democrático da nossa história, e, simultaneamente, de criar ou renovar instituições capazes de sobreviver ao esgotamento dos próprios movimentos (ao menos em sua forma original), estabelecendo condições inéditas para que novas lutas venham a gerar um processo de transformações cumulativas (2005: 204. Grifo meu.)

O comentário de Fortes se insere em um debate sobre as esquerdas no começo do governo Lula, no qual uma das polêmicas versava sobre a dicotomia entre movimento e institucionalização, contenda que seria renovada pela experiência da esquerda na presidência com Lula. Em parte, este também é o tema deste artigo e por isso sublinhamos o "sobreviver" das instituições, pois é exatamente isso que está em questão agora.

Todavia, em vez de buscar uma síntese dos polos movimento e instituições, como fez Fortes, nossa proposta é deslocar os termos do debate. Não há como determinar a justa medida entre lutas sociais e seu enquadramento nas instituições nem como delimitar o momento em que esta relação assume um ponto ótimo. Nossa atual crise é expressão dessa impossibilidade, sobretudo pela tensa relação entre o lulismo e as jornadas de junho de 2013. O fundamental é, então, verificar em cada situação concreta quem detém a hegemonia da relação entre o social e o político, entre as lutas e as instituições: desde a perspectiva das classes subalternas, importa saber se esta relação se dá no "terreno do outro", expressão tomada da análise de Werneck Vianna sobre o PCB (1989) ou se as lutas foram capazes de produzir um terreno de qualidade distinta para a ação, abrindo às classes subalternas um novo campo de forças.

A ideia de um terreno onde se dá a disputa entre as classes e grupos sociais é constitutiva da própria noção de hegemonia em Gramsci. Guiseppe Cospito, autor do verbete "Hegemonia" no Dicionário Gramsciano afirma que "o terreno no qual se desenvolve 'a luta pela hegemonia' é o da sociedade civil" (2017: 366). A importância da noção de terreno está em apreender as várias dimensões desta luta: "terreno econômico" e "em paralelo nos terrenos ideológico, jurídico, religioso, intelectual, filosófico" (2017: 367). O objetivo é superar a interpretação mecânica entre estrutura (economia) e infraestrutura (política), no qual esta seria mero resultado daquela. A sociedade civil, em sua multiplicidade, é o terreno da luta e a hegemonia política é o ponto de contato (2017: 366) da sociedade com as instituições (sociedade política). É por isso que, em Gramsci, o partido político é central: sua função é articular essas duas dimensões (2017: 368).

Gramsci sistematiza três camadas "das relações de força" (2002: 36) que constituem o campo de ação das classes em luta. Há a camada estrutural, que é "objetiva, independente da vontade humana". Gramsci ilustra essa camada afirmando que "esta relação é o que é, uma realidade rebelde: ninguém pode modificar o número de empresas e de seus empregados, o número de cidades com sua dada população urbana" (2002:40); há também a camada "política", na qual se desenvolve a luta de hegemonia propriamente dita 
(2002: 41); e, por fim, a militar, que envolve as relações entre as nações (2002: 43). A camada política é aquela em que se define, para as classes subalternas, se estão lutando no "terreno do outro" ou em terreno próprio.

Faz sentido voltar à conclusão de Fortes, mas para ir além do diagnóstico sobre a institucionalização ou não, investigando se, após as mobilizações, as classes subalternas seguiram no terreno do outro ou conseguiram firmar seu próprio terreno. Faremos isso brevemente para cada ciclo de lutas no Brasil do século XX. O primeiro ocorreu entre 1917 e 1919, marcado pelas greves gerais do anarcosindicalismo, que conquistaram, ao menos na letra da lei, o reconhecimento dos sindicatos, redução da jornada de trabalho e outros direitos. Contudo, a conjuntura posterior ao ciclo foi marcada por uma brutal repressão ao movimento operário, com fechamento de sindicatos e perseguições e com a instalação de sucessivos estados de sítio entre 1922 e 1926. O terreno do outro se impôs às lutas deste primeiro ciclo, mas não a ponto de anular o movimento tenentista que se forma em paralelo às lutas sindicais. Os tenentistas, com suas reivindicações democráticas, foram responsáveis pelo segundo ciclo de lutas, entre 1928-1930, o que foi decisivo para que a oligarquia da República Velha perdesse as condições de governar. Vem a Revolução de 1930, sobre a qual o tenentismo se divide, posto que mais uma vez as classes subalternas foram excluídas, mantendo-as, portanto, no terreno do outro.

O terceiro ciclo foi o da luta antifascista com a Ação Nacional Libertadora (ANL) entre 1933 e 1935, com os grandes atos de rua em defesa da democracia e os enfrentamentos na qual os integralistas (movimento fascista nacional) saíram derrotados. O que se seguiu a esse ciclo foi o Estado-Novo, um dos momentos de maior fechamento democrático da nossa história. Quando o terreno das lutas foi reaberto, com a mobilização para que o Brasil entrasse na 2a Guerra contra o nazi-fascismo e em seguida, com o fim do conflito, nas lutas pela redemocratização entre 1945 e 1947, muitos dos sentidos da ANL foram retomados, mostrando a importância daquele ciclo. O terreno seguia sendo o do outro, mas estava diferente, mais aberto, mais fértil para os direitos.

A conjuntura do imediato pós-guerra foi, até aquele momento, a mais rica em conquistas para as classes subalternas: Constituinte, eleições diretas com participação dos comunistas, greves e lutas agrárias. Outra vez, o resultado imediato foi de fechamento, com a proscrição do PCB em 1947. Mas, a partir de 1950, com Vargas, e até 1964, as dinâmicas de luta foram reabertas. Se não era ainda um terreno pleno de direitos, tampouco está correto afirmar que as lutas não tiveram êxito em mudar as instituições. Os sindicatos e organizações camponesas conheceram liberdade inédita. Estudantes e movimentos culturais floresceram. Dois grandes ciclos de luta marcam o período: um durou de 1953 a 1957, com greves de massa e nacionais, aumento do salário mínimo e a criação da Petrobrás. Esse ciclo tem um resultado contraditório com a eleição de Jânio Quadros em 1960, que capturou a insatisfação com um discurso antipolítica e a eleição de João Goulart, para vice-presidente, representando o sentimento generalizado por direitos. O segundo ciclo inicia-se em 1961 com a greve geral da legalidade que garantiu a posse de Jango na presidência, confirmando que o terreno de lutas tinha mudado. A tal ponto que as elites, percebendo que estavam prestes a perder o controle do terreno em que se dava a luta por hegemonia, organizam o golpe militar de 1964 para reorganizar as disputas políticas e retomar o controle da situação. Ainda nessa mesma dinâmica, nem mesmo o autoritarismo foi capaz de impedir um novo ciclo de lutas, entre os anos 1967 e 1968, com os festivais de música, as lutas estudantis, a passeata dos 100 mil e as Greves de Contagem e Osasco. O resultado desse ciclo foi uma radicalização ainda maior dos militares, com o fechamento definitivo do regime via o AI-5. 
Nessa sintética retrospectiva, nossa hipótese ganha força. Todas essas lutas tiveram conquistas imediatas, com exceção do ciclo de 1968, já sob a ditadura. Nenhuma delas, entretanto, foi capaz de consolidar instituições sólidas e direitos garantidos plenamente. Não obstante, após cada ciclo de lutas, o terreno da disputa de hegemonia se alterava substancialmente. As lutas que pareciam derrotadas serviam para sedimentar uma memória mais profunda, com seus sentidos mobilizados e reordenados em processos de médio prazo e de acúmulos daquilo que E. P. Thompson (1987) chama de fazer-se da classe. Não há um setor da esquerda que questione, por exemplo, a importância das greves de Contagem e Osasco de 1968 para as lutas operárias que explodiram dez anos depois.

Mas, de fato, é o ciclo de lutas sociais da redemocratização que leva as classes subalternas a outro patamar. O terreno para a hegemonia com a Constituição de 1988 foi de fato inédito. Nada disso seria possível se as lutas não conquistassem a representação política, com a legalidade dos partidos de esquerda. Esta centralidade aparece, de modo original, na já citada pesquisa de Brandão sobre o PCB, na qual ele destaca a questão da "(i)legalidade" como chave para que o partidão não tenha realizado plenamente sua vocação. Para Brandão, "a inexistência de um partido operário legal na arena política tornava ostensivamente mais lento e difícil o processo de formação de uma consciência política de classe" (1997:169). Erros e debilidades passam a ser contextualizados e o papel do comunismo no Brasil pode ser positivamente reavaliado se concordamos que "a ausência de uma organização política legal é um impedimento estratégico, prévio, à formação de uma classe operária 'autônoma'"' (1997: 171).

A conquista da representação pelo PT é o primeiro momento de formação do lulismo ao consolidar um horizonte de expectativas (a conquista do Estado) para as classes trabalhadoras que protagonizaram a redemocratização. As mobilizações pela Diretas Já em 1984 e em torno da Constituinte impulsionaram aquele horizonte.

Com relação à Constituinte, esse impulso resultou na dinâmica mobilizadora das emendas populares, analisada por Francisco Whitaker (1989), Adriano Pillati (2008), entre outros. Há, contudo, uma outra dimensão que merece atenção e que é menos tematizada no debate acadêmico: o intenso debate que ocorreu no PT e nos movimentos sobre participar ou não da Assembleia Constituinte. Essa polêmica resultou em uma decisão de participar, porém impulsionada por proposta de Constituição elaborada pelo partido, única agremiação que fez algo do tipo, convocando os movimentos em torno de uma plataforma concreta e com isso pautando a agenda de debates.

A Constituinte foi o primeiro grande laboratório em que o petismo precisou coordenar suas estratégias de mobilização e conflito com as dinâmicas de negociação e pactuação necessárias à disputa por posições na institucionalidade. Caso o ciclo de lutas da redemocratização não tivesse investido em disputar a Constituinte por dentro e por fora, 0 resultado mais provável era a continuação da lógica do colégio eleitoral de 1985, com a pactuação entre as elites produzindo uma democracia restrita. Em suma, as classes subalternas permaneceriam no terreno do outro. O lulismo é um dos resultados dessa combinação e da criação do novo terreno de lutas. O desfecho do processo é muito significativo neste sentido: o PT manteve a radicalidade das lutas votando contra a Constituição, mas assumiu a institucionalidade como sua ao assinar a Carta.

O intenso debate no partido e nos movimentos reforça nossa hipótese de que outros caminhos estavam abertos para o petismo e que levariam à coletividade do partido para longe do caminho que veio a dar no lulismo. 
Josué Medeiros

Já em 1984, no III Encontro Nacional do PT, apresentaram-se visões diversas sobre o processo, umas mais insurrecionais e outras mais pragmáticas. O Diretório Nacional petista agendou para o dia 07 de julho daquele ano o debate sobre a Constituinte e preparou um caderno com a diversidade de posições existentes no partido. O núcleo da polêmica se dava sobre a participação ou não nas mobilizações pela Assembleia Constituinte. Mesmo no grupo de Lula havia dúvidas. Rui Falcão afirmava que "não se trata de combatê-la ou defendê-la por princípio, mas sim de saber se, nesta conjuntura em particular, ela pode constituir-se numa palavra de ordem mobilizadora" (DN-PT, 1984: 0607). Na maioria lulista, contudo, prevaleceu a participação, sintetizada por José Álvaro Moises: "a convocação de uma constituinte é, hoje, uma decorrência natural e necessária da campanha pelas diretas já" (DN-PT, 1984: 14).

Para alguns setores marxistas do PT, uma Constituinte feita na sequência das eleições indiretas serviria para recompor a hegemonia burguesa. Augusto de Franco escreveu que o objetivo da burguesia era garantir, com a Constituinte, "um reordenamento global da forma de dominação", assim como fora feito em 1946 (DN-PT, 1984: 02-03). José Genoíno, do Partido Revolucionário Comunista (PRC) defendeu que a constituinte "tende a ser a legitimação de um novo pacto entre as elites para substituir o regime ditatorial-militar" (DN-PT, 1984:12). Ambos falam na Constituinte como armadilha que vai aprisionar o PT e retirar dos trabalhadores "sua capacidade de agenda".

Outras organizações internas ao PT e que também era filiadas ao marxismo defendiam a participação na Constituinte, o que mostra a diversidade do petismo. Jorge Almeida, do Movimento Comunista Revolucionário (MCR), faz um chamado ao PT para que lidere a luta pela Constituinte enquanto continuidade da luta pelas Diretas: "Todos os argumentos contra a Constituição Livre caíram por terra. Como, antes, caíram os contra a Anistia e as Diretas. Assumir esta bandeira é urgente. Levá-la as ruas, inadiável" (DN-PT, 1984: 09). Virgílio Guimarães, da Democracia Socialista (DS), via a Constituinte como a maneira mais consequente de "lutar pela derrubada do regime militar e de dar continuidade à mobilização das Diretas" pois é "a bandeira democrática que expressa de forma mais clara e radical a exigência de uma nova ordem política, econômica e social", sendo, portanto, o único caminho pelo qual o PT pode "evitar a conciliação de classes, uma vez que uma Constituinte livre permite a organização independente dos trabalhadores". (DN-PT, 1984: 16-17).

A opção por disputar o processo por dentro se consolidou no Encontro Extraordinário de janeiro de 1985 com "a campanha de mobilização e propaganda pela Assembleia Constituinte Livre, Soberana e Democrática" (PT, 1998: 189). O petismo lança a luta por uma Constituinte exclusiva em 28 de junho de 1985 e propõe um processo com comissões municipais populares responsáveis por elaborar as propostas que seriam enviadas à Assembleia. Mesmo derrotado, com convocação do Congresso Constituinte não exclusivo, o PT manteve a estratégia de combinar "dentro" e "fora", recusando a tática de ruptura das organizações de esquerda que chamavam pela "não participação na farsa constitucional" (O Trabalho), ou pela necessidade de o PT "denunciar às massas o verdadeiro caráter de classe da constituição" (Convergência Socialista).

Importante ressaltar também que esta divergência não ficou restrita ao partido, atravessando os movimentos sociais do ciclo de lutas. No II Congresso da Central única dos Trabalhadores (CUT), em 1986, o setor majoritário (Articulação Sindical, do qual Lula fazia parte) propôs priorizar a negociação com os parlamentares enquanto os setores minoritários investiram em uma estratégia mais voltada para a pressão das massas contra os 
Josué Medeiros

constituintes. A votação terminou rigorosamente empatada, com um número considerável de delegados identificados com Lula votando conjuntamente com a oposição cutista. 0 impasse forçou os dois blocos a negociar uma resolução que combinou as duas formas de luta (CUT: 1986). Essa combinação, que veio a ser o centro da estratégia política do petismo, demonstra uma dinâmica de composição da pluralidade presente no partido e nos movimentos que está no DNA do fenômeno político do lulismo.

Voltando ao projeto de Constituição do PT, o texto teve como coordenador o jurista Fábio Konder Comparato. Muitas de suas propostas foram modificadas no debate interno do partido. Por exemplo, no documento do jurista, o foco principal estava na noção de desenvolvimento (1986: 16), adensada com o termo democrático com vistas a se diferenciar do desenvolvimentismo que se liga com "a política governamental de Juscelino Kubitscheck" (Idem). Já o projeto final do PT priorizou o poder popular, entendido como um quarto poder para além da institucionalidade liberal clássica.

De todo modo, o texto final do partido buscou mais uma vez compor as duas visões, reforçando a estratégia política do petismo de compor dentro da pluralidade:

De um lado a perspectiva de instauração dos direitos e garantias, individuais e coletivas, de todos os seres humanos. De outro, a preocupação com o afloramento de um conjunto de instituições, princípios e diretrizes constitucionais que propicie condições efetivas de controle popular sobre o poder público e o funcionamento da sociedade como um todo (PT, 1987: VI).

É possível observar a presença desses dois eixos nos sentidos e símbolos do /ulismo, embora o primeiro eixo (direitos e garantias individuais na institucionalidade burguesa) tenha prevalecido, conforme veremos. Nem mesmo a visão mais moderada de participação popular que constava na versão de Comparato - iniciativa legislativa de cunho popular, referendos e plebiscitos que consistem em "atribuir aos cidadãos um poder de sanção tradicionalmente exercido pelo chefe de Estado" (20) - foram estimuladas pelo lulismo. Este, contudo, não abriu mão dessa simbologia participativa, elaborando uma linguagem própria de participação através das conferências e conselhos.

O fato é que o projeto petista de Constituição defendia uma democracia popular, radical e direta que, na prática, superaria os limites da democracia liberal representativa. Seria a formação não apenas de um terreno próprio para a luta de hegemonia, mas de um novo sistema político. O texto afirmava que "todo poder é exercido por delegação e participação popular direta" (PT, 1987: 1), propunha a criação dos "conselhos populares" (PT, 1987: 22) e ainda o controle popular "na prestação dos serviços públicos, através dê conselhos de usuários eleitos diretamente e que terão competência decisória" (PT, 1987: 72) e na elaboração e execução do seu Plano Nacional de Desenvolvimento (PT, 1987: 77). Esse caminho seria bem diferente do que se configurou no lulismo, que atuou exclusivamente por dentro das instituições existentes.

Se nessa dimensão da participação o afastamento entre o lulismo e as sínteses do petismo nos anos 1980 é evidente, há uma outra dimensão igualmente importante no projeto de Constituição do PT que prevaleceu com força durante os governos Lula: o vínculo da cidadania com a resolução dos problemas sociais. No tópico da igualdade, o partido defendeu que "o poder público promoverá, mediante programas específicos, a igualdade social, política, econômica e educacional" (PT, 1987: 7).

Vale destacar ainda algumas outras questões do projeto partidário. Uma delas foi a centralidade da defesa do direito ao aborto (PT, 1987: 14), algo que o partido seguiu 
afirmando durante os governos Lula, ainda que a administração não tenha demonstrado avanços nesse tópico. Por fim, de modo inovador, o PT elaborou a ideia de "direito ao meio ambiente sadio e em equilíbrio ecológico" (PT, 1987: 17) como parte da Constituição, dimensão que, no lulismo, enfrentou tensões diante da prioridade para o desenvolvimentismo econômico e social.

Com a Constituição promulgada, o PT fez um balanço negativo da carta (o que justifica o voto não ao texto) devido à permanência de estruturas políticas e econômicas herdadas da ditadura militar. Para o partido, estava em curso mais um acordo entre as elites para deixar tudo igual. Ao mesmo tempo, porém, a perspectiva de uma vitória com Lula nas primeiras eleições diretas desde 1960 renovou os impulsos do petismo para a conquista das instituições. O pleito presidencial de 1989 seria uma nova chance de firmar um terreno próprio de um modo profundo na vida política nacional. A derrota naquela disputa e a posterior hegemonia neoliberal iniciada com Collor de Mello e consolidada com FHC mostraram que a força do terreno da burguesia seguiria se impondo às lutas e marcaria decisivamente o modo como os direitos da Constituição de 1988 seriam efetivados na vida concreta da maioria da população.

\section{Instituições e lutas em meio ao terreno da hegemonia neoliberal}

O lulismo não é apenas um dos frutos políticos que decorrem do virtuoso processo de lutas sociais dos anos 1980; é também resultado das muitas derrotas que marcam a última década do século XX. As eleições presidenciais de 1989 e 1994 foram insufladas em expectativas com a possibilidade de conquistar o Estado. Havia muita pluralidade nos movimentos e no PT e, ao mesmo tempo, muita unidade em torno deste objetivo maior. Em 1993, o grupo de Lula perdeu a direção partidária de modo inédito, porém a nova maioria o reconduziu ao cargo de presidente do partido. Já na CUT, em 1994, pela primeira vez em sua história foi formada uma chapa unitária na direção. A frustração decorrente dessas derrotas teve que ser digerida pelo petismo já no novo terreno político do outro que se impôs com a hegemonia neoliberal.

Já tratamos da revisão constitucional de 1993, mas aquele processo foi apenas um ensaio. Ao longo da década de 1990, diversas reformas constitucionais foram aprovadas pela coalizão neoliberal que ganhou o executivo com FHC e que comandava o Congresso: Reforma do Estado, Previdenciária, Lei de Responsabilidade Fiscal, Privatizações. Além, é claro, da emenda constitucional que permitiu a reeleição do sociólogo.

Esse processo institucional reverberou na sociedade de dois modos. Primeiro, pela questão da verdadeira destruição da classe trabalhadora enquanto sujeito coletivo com o desemprego estrutural. Segundo, pela redução do horizonte político dos direitos.

Começando com a questão do desemprego, que era relativamente nova para o sindicalismo. Paulo Fontes registra em seus estudos sobre as classes trabalhadores de 1940 a 1964 que o mercado de trabalho estava "sempre em expansão", e o máximo que ocorria eram "surtos de desemprego" (2009: 61-63). Murilo Leal, analisando o sindicalismo no mesmo período, afirma que "o crescimento do setor metalúrgico gerava uma fome de braços. Absorvia a força de trabalho incessantemente". (2011: 52-53).

A primeira vez que os movimentos se deparam com o problema do desemprego durante a recessão de 1980 a 1984, não por acaso o período com menos greves dos anos 1980. Segundo a CUT ${ }^{1}$, o desemprego saltou de 2,8\% em 1979 para 4,3\% em 1981, atingindo o pico em 1983, com a taxa de 4,9\%. Já em 1984, retoma um viés de queda para 
4,3\%, e em 1985 ocorre uma baixa significativa, fechando em 3,4\%, em um contexto de retomada do conflito grevista. A luta contra o desemprego ganhou protagonismo no período e, em setembro de 1983, a CUT promoveu um "Acampamento dos Desempregos" no Ibirapuera. A Plenária Nacional da CUT em maio de 1984 registrou movimentos iguais em Minas Gerais, Espirito Santo, Ceará, Paraná e Rio Grande do Sul.

A situação dos anos 1990 foi diversa: O desemprego aumentava a cada ano, saltando para $5 \%$ em 1990, 7,2\% em 1991, até atingir 12\% em 1999. As categorias mais fortes sentiram o golpe. Em 1991, o então presidente do Sindicato dos Metalúrgicos do ABC, e que seria eleito presidente nacional da CUT em 1994, Vicentinho, explica a não adesão à greve geral de 22 e 23 de maio: "A greve geral era um processo para a qual a gente também vinha se preparando. Mas a gente foi percebendo que os trabalhadores cansados, e também desconfiados, se o país ia parar ou não, não estavam animados" (PT: 1994). Jefferson José da Conceição registrou que a base do sindicato de São Bernardo e Diadema tinha, em janeiro de 1990, 200.497 trabalhadores, o que foi reduzido para $110.810 \mathrm{em}$ janeiro de 1998 (PT: 1998). Na cidade de São Paulo uma das memórias mais impactantes do petismo (e que me foi relatada em inúmeras entrevistas) é a da privatização da Companhia Municipal de Transportes Coletivos pelo prefeito Paulo Maluf. De um dia para outro nada menos do que 20 mil motoristas e trocadores foram demitidos, esfacelando a base sindical na cidade, que jamais se recuperou.

Ao enfraquecimento orgânico da classe trabalhadora soma-se à ofensiva política levada a cabo por FHC na esteira do Plano Real. Adalberto Cardoso argumenta que as categorias lidaram com a reestruturação neoliberal de distintas maneiras, colhendo frutos diversos das suas múltiplas estratégias. Por um lado, a Força Sindical se constituiu apoiando todo esse processo; por outro, para o sociólogo, o Plano Real derrotou Lula nas eleições presidenciais e também dobrou a CUT ao romper com o modo de funcionamento dos seis pacotes econômicos dos anos 1980, contra os quais o sindicalismo lutava. Naquela década, os pacotes conquistavam apoio inicial junto à sociedade por conseguir debelar a inflação. Porém, isso não se sustentava, a alta dos preços voltava com mais força e "o fracasso de cada novo pacote econômico alimentava imediatamente o movimento sindical, e novas greves eclodiam". Em suma, "inflação explosiva e as tentativas frustradas de domá-la baseadas na contenção de salários foram combustíveis poderosos num ambiente bastante favorável à ação de massas" (2000: 51-52).

O Plano Real logrou derrotar a inflação de modo mais permanente, e com isso abriu a possibilidade para uma contraofensiva empresarial e governamental contra os movimentos sociais, tendo como marco o enfrentamento que tomou corpo na greve dos petroleiros de 1995. Nesse conflito, o presidente recém-eleito se aproveitou da altíssima popularidade conferida a ele pelo processo eleitoral e impôs uma reconfiguração do terreno de luta pela hegemonia, recusando conferir legitimidade à greve.

O resultado dessa soma de perda de legitimidade política e desemprego estrutural foi um enfraquecimento brutal das lutas sociais. Vito Gianotti registra, com base em dados do DIEESE, que "a partir de 1992, as greves diminuíram fortemente e, em 1999, o montante de greves e grevistas, sempre segundo o DIEESE, chegou a ser 2\% dos vinte milhões de 1989" (2007: 287), ano recorde do movimento grevista.

Diante desse quadro, o sindicalismo e os movimentos sociais em geral se reinventaram com a noção "cidadã" e isso foi decisivo para o /ulismo. Não foi um processo simples e unívoco, pois se deu sob pressão da hegemonia neoliberal. Do ponto de vista das lutas, tratava-se de avançar no que Vera Teles chamou de "possibilidades da cidadania se 
enraizar nas práticas sociais" (1996: 91). Uma vez conquistada a Constituição, era preciso efetivá-la. Mas como fazer isso em meio ao que Chico de Oliveira chama de "anulação da política" (2000: 59), com a privatização do público e a destruição da classe? Para o sociólogo, esses processos eram um dado histórico e estrutural da nossa formação social, mas ao longo do século XX as classes subalternas lutaram pela ampliação da política, culminando na Constituição de 1988, quando "toda a reivindicação anterior ganhou foros de direito, na letra da Carta Maior". (2000:65).

O problema foi que a década de 1990 reverteu esse processo de mobilização em uma dupla dinâmica: de modo pulverizado nas empresas, com a individuação dos conflitos no chão da fábrica entre o empregado e o $\mathrm{RH}$, "onde a possibilidade de fala como recurso discursivo para a reivindicação é completamente anulada". (2000: 71); e, de modo global, na relação entre Estado e as classes, com o bloqueio às tentativas de reinvenção das classes populares via movimentos coletivos. Oliveira destaca o caso das câmaras do setor automobilístico (acordos entre patrões e empregados para aumentar a produtividade e manter empregos com a ajuda estatal via redução de impostos) desfeitas por FHC: "O acordo não interessava (...) em primeiro lugar e acima de tudo porque ele constituía um importante recurso político, uma criação política de uma importante categoria dos trabalhadores, central na luta de classes no Brasil" (2000:76).

Essa estratégia de diálogo e pactuação que foi muito polêmica dentro do petismo no começo dos anos 1990 seria retomada com força no lulismo, com o Conselho de Desenvolvimento Econômico e Social e o Fórum do Trabalho, ambos criados em 2003. Nesse momento, Chico de Oliveira se tornara um crítico de Lula, mobilizando contra o governo os argumentos que, em 2000, ele criticava como "sectários de esquerda" (Idem).

A polêmica era legítima e representava visões distintas de como lutar para enraizar os direitos. Em parte, o petismo acreditava que a conquista do Estado supostamente garantiria essa efetivação (essa crença é estruturante do lulismo). Enquanto isso, era preciso resistir e então os movimentos se polarizaram entre a opção de manter viva a verve classista e de enfrentamento versus o caminho da reinvenção pela cidadania. Na CUT, essas disputas ocorreram no calor dos acontecimentos, entre o III CONCUT, em 1988 ao V CONCUT, em 1994.

O grupo do Lula defendeu aderir à experiência da socialdemocracia europeia, com uma estrutura verticalizada via confederações, responsáveis por negociar contratos coletivos nacionais e apoiada por uma estrutura horizontal de organizações por local de trabalho vinculadas aos sindicatos, cujo sentido seria o de confrontar a tentativa empresarial de limitar os conflitos nas empresas ao setor dos $\mathrm{RH}$. O documento que apresenta esse projeto é famoso na memória do petismo: a chamada Tese 10, texto do grupo do Lula para o III CONCUT, subscrito por 106 sindicatos, muitos deles sem sequer ler o conteúdo somente pela referência política em Lula, o que é reconhecido pelos dois lados da memória cutista. Foi na Tese 10 que, pela primeira vez, Lula e seu entorno apresentaram uma visão de movimento sindical substancialmente distinta daquela animada pelo petismo até então. 0 texto afirma a necessidade de transformar a CUT em uma central "orgânica", superando a concepção de "movimento social". Isso significava fortalecer o aspecto negocial do sindicalismo, em detrimento da dimensão do conflito, e também o viés vertical da estrutura em vez do seu aspecto horizontal.

A resistência a isso somou quase metade da CUT (o grupo do Lula tinha um membro a mais na executiva) e chegou a ser majoritária no PT. Juarez Guimarães registra que a participação em fóruns de negociação tripartite (formato negocial e diluidor dos conflitos) foi 
rejeitada pelo partido em 1990 (1990: 85) e aprovada na CUT no mesmo ano, como relatam Neto e Gianotti (1991: 60-61). Prevaleceu, no petismo, a posição de Lula e seu entorno, o que foi decisivo para a constituição do lulismo: na Plenária Nacional da CUT de 1990 pela primeira vez aparece o termo "propositivo" como eixo estruturante da nova estratégia central, como parte do chamado "sindicalismo cidadão" e da decisão de participar dos fóruns com o governo e empresários. Já em 1991, no IV CONCUT, a central estava verticalizada (sem delegados da base) e com a vitória do que Iran Jacome Rodrigues e Heloísa Martins de Souza chamam de "uma mudança radical da ação sindical na década de 90, especialmente no que diz respeito às demandas do sindicalismo (...). A agenda sindical se voltou para o interior da empresa" (1999: 166).

Tal estratégia foi exitosa para o sindicalismo metalúrgico do ABC. Glauco Arbix e Jacome Rodrigues analisaram esse novo padrão negocial, no qual "a agenda" de discussão entre as empresas e o sindicato - e, o que é mais importante, via comissão de empresas "foi ampliada significativamente", abrangendo temas tais como "salários; condições de trabalho; desverticalização; terceirização; trabalho em grupo; participação nos resultados; e, o mais importante, flexibilização da jornada de trabalho" (1996: 79). Os acordos conduzidos por essa via levaram os autores - e também parte do sindicalismo - a defender o estabelecimento de um novo padrão de relações de trabalho, "que só será efetiva se desmontar o arcabouço da velha legislação corporativa" (1996: 85). Foi exatamente isso que o lulismo tentou fazer com o Fórum do Trabalho.

Para Cardoso, a chamada "greve dos demitidos" em 1998, é simbólica da nova legitimidade cutista, quando três mil operários demitidos seguiram a orientação do sindicato e entraram nas fábricas para trabalhar normalmente, levando as empresas a interromper a produção. Após 44 dias desse conflito, o patronato cedeu e recontratou os grevistas (2003: 54-55). Contudo, ele cita os metalúrgicos de Minas Gerais e São Caetano do Sul, lugares em que essa estratégia não funcionou e levou à derrotas (2003: 57-58).

O problema fundamental é que CUT aderiu à concepção sindical socialdemocrata menosprezando tanto os impactos do desemprego estrutural (este um fenômeno global) quanto o peso da legislação sindical corporativista (esta uma peculiaridade nacional). 0 resultado foi uma fragilização da solidariedade de classe. A fragmentação e despolitização, dinâmicas centrais da hegemonia neoliberalismo, encontraram no corporativismo sindical um terreno fértil para prosperar e que tem na Força Sindical seu maior exemplo. Contudo, também o sindicalismo cutista - remodelado pela verticalização e pela prioridade da negociação em detrimento do conflito - foi impactado pela lógica do neoliberalismo, o que ajuda a entender muitos dos impasses do lulismo.

Nas lutas para enraizar os direitos da Constituição outras alternativas se apresentaram para além desse percurso sindical da negociação. A dinâmica da democracia participativa, especialmente o Orçamento Participativo (OP), foi uma das mais potentes criações nesse processo, ao mesmo tempo, aquela que mais ficou de fora do lulismo.

O elogio ao OP enquanto criação democrática é amplamente presente na literatura brasileira e internacional. Chico de Oliveira, Maria Célia Paoli e Cibele Rezek qualificam o OP como "extraordinária invenção política que cria "um nível intermediário entre a representação clássica em vias de esgotamento e a democracia direta sonhada, mas não realizável" e que se filia à longa linhagem conselhista da Comuna de Paris (2003:123). Evelina Dagnino entende o OP como um dos pilares da "nova cidadania" que produz novos tipos de "pertencimento" e que significa também uma "nova fase dos movimentos sociais, representada pelo seu esforço de se adequar à institucionalidade democrática" (1996: 109- 
110). Boaventura de Souza Santos afirma que o OP faz parte de "uma reforma radical do Estado, fazendo da participação não apenas um elemento de maior transparência governamental", mas também que "suponha uma outra forma de relação entre governantes e governados e, portanto, de cidadania e democracia" (2002: 668-669).

Acompanhamos Leonardo Avritzer quando ele vincula o OP com o PT em seu balanço sobre "as instituições participativas no Brasil". Estas, segundo o autor, possuem dois pilares, "os conselhos de política pública e o orçamento participativo", os primeiros inscritos na Constituição enquanto o OP é criação política autônoma. (2007: 411-414). Entendemos, portanto, que os sentidos do OP se conectam tanto com a própria Carta de 1988 quanto com o projeto de Constituição do PT e sua ênfase no poder popular. Já os conselhos, por sua vez, embora também se relacionem com a Constituição, podem ser capturados pela técnica neoliberal, principalmente pelo seu caráter consultivo, o que permite limitá-los mais facilmente a mero instrumento da "governabilidade", conforme ocorreu inúmeras vezes no lulismo. Assim, não é menos importante para compreender os impasses do lulismo que tais conselhos foram priorizados enquanto não houve qualquer tentativa de OP nacional. Tratase de uma escolha que se deu contra um importante acúmulo de processos do petismo e dos movimentos sociais. Carla Bezerra mostra que a participação passou por "uma mudança substantiva", deixando de ser o ato de "construir o poder popular" para virar "participação como método de governo" (2014: 14).

Um marco dessa mudança é expressão 'modo petista de governar', surgida em livro organizado por Jorge Bittar em 1992, então titular da Secretaria Nacional de Assuntos Institucionais. A soma de êxito administrativo com êxito eleitoral contribuiu para esse enquadramento do OP e das dinâmicas participativas enquanto técnica de governo que era experimentada nas cidades, as quais serviam como laboratório para um futuro governo nacional do petismo. A relação entre escala municipal e federal sempre se fez presente na diversidade coletiva do PT e sempre de modo tenso. A vitória de Lula em 2002 foi precedida pela "onda vermelha" em 2000, quando o PT saiu das eleições municipais como o partido vitorioso e que usava suas administrações como plataforma para a eleição geral. Em 2012, no auge político do lulismo, a relação se inverte: é o governo federal que impulsiona as vitórias eleitorais em prefeituras, sobretudo a retomada de São Paulo com Fernando Haddad.

Por fim, é preciso ainda mencionar o Movimento dos Trabalhadores Sem Terra (MST) como um outro caminho alternativo ao lulismo na tarefa de efetivar os direitos constitucionais. Alternativo, porém não contrário.

O MST é importante em várias dimensões. Primeiro, porque foi capaz de mobilizar novos sujeitos políticos - os mais pobres do campo - justamente quando a classe trabalhadora urbana estava fragilizada; segundo, porque organizou um caminho que priorizava o conflito como estratégia para pressionar as instituições e viabilizar a negociação, diferente do caminho negocial cutista; terceiro, porque essa mobilização dos excluídos e a manutenção do conflito se apoiavam na promessa de igualdade social e dignidade consolidadas pela Constituição. Ou seja, também foi uma escolha de participar, assim, como a CUT, porém de fora para dentro das instituições. E quarto, porque essa mobilização dos mais pobres se conectava estratégicamente com a liderança de Lula.

O MST também é um consenso no debate acadêmico. Werneck Vianna fala em "massificação da cidadania", a qual tinha por "expressão paradigmática o movimento dos trabalhadores sem terra" sobretudo "em razão da singularidade de suas demandas sociais: porque o seu objeto é a terra - um bem de natureza pública -, cada avanço seu na agenda 
Josué Medeiros

da democratização social tem incidido positivamente no avanço da democracia" (1997:53). Para José Murilo de Carvalho, "o MST representa a incorporação à vida política de parcela importante da população" e embora "seus métodos, a invasão de terras públicas ou não cultivadas" sejam a princípio ilegais, se legitimam no confronto com a "opressão secular de que foram vítimas e a lentidão dos governos. Em suma, o MST é o melhor exemplo de um grupo que, utilizando-se do direito de organização, força sua entrada na arena política, contribuindo para a democratização do sistema" (2001: 203).

Starling e Schwarcz lembram a importância da Marcha dos 100 mil organizada pelo MST em 1997, resultado de meses de caminhada de milhares de ativistas (2015: 382). Essa lembrança é importante para retomar os vínculos entre o MST e o lulismo: os Sem Terra se encontram com Lula na sensibilidade da urgência com relação aos pobres e aos problemas ainda coloniais da fome e da miséria. Poucos anos antes da Marcha dos 100 mil, Lula organizou as Caravanas da Cidadania, em 1992/1993, se relacionando diretamente com o povo mais excluído dos rincões e refazendo sua imagem do conflito para uma simbologia da inclusão, o que indica que a moderação do "Lula Paz e Amor" não tem apenas o sentido negativo que muitas vezes aparece na esquerda. Alguns anos depois, já presidente, ele colocaria a superação da fome no centro da agenda nacional e seu sucesso nessa missão foi fundamental para consolidar o fenômeno do lulismo.

\section{O lulismo na política brasileira}

O lulismo é o fenômeno que ocupa o centro de gravidade das diversas temporalidades da política brasileira contemporânea. Seu patrimônio resulta do virtuoso processo de profundas mudanças econômicas, sociais, políticas e culturais no Brasil desde 2003, quando Lula iniciou seu primeiro governo. No presente, a formação de uma ampla coalizão entre empresários, elites políticas, parcela do judiciário e classes médias em favor do golpe parlamentar de 2016 e da prisão de Lula em 2018 teve como dimensão mais imediata a interdição do lulismo através de uma radical mudança do padrão de competição eleitoral estabelecido pela Carta de 1988 e cujo objetivo mais geral vem sendo o de anular os sentidos democráticos da Constituição.

Já o passado é mobilizado com o objetivo de compreender os fundamentos deste fenômeno político, tal como fizemos aqui vinculando-o ao petismo e à Constituição. Por fim, interroga-se sobre o futuro da liderança de Lula, da vitalidade do petismo e da sobrevivência do lulismo - mais ainda diante da hipótese de um bolsonarismo turbinado pelos mais pobres graças ao Auxilio Emergencial caso este se torne permanente. Neste questionamento se insere o próprio amanhã da democracia brasileira.

Ninguém sintetizou melhor os sentidos políticos desse fenômeno do que Singer (2012). Para ele, Lula conseguiu produzir, a partir de um programa reformista fraco e de uma prática de arbitragem dos conflitos de classe, um deslocamento que separou politicamente, pela primeira vez na história do Brasil, os mais pobres dos mais ricos. Os setores mais pauperizados da nossa estrutura de classes - que ele chama de subproletariado (2012: 77) - sufragaram Lula em 2006 e Dilma em 2010 assim como haviam feito com Collor em 1989 e FHC em 1994 e 1998. Trata-se de um realinhamento eleitoral iniciado em 2006 e que tem potencial de durar décadas. A nova vitória de Dilma em 2014, posterior ao livro, foi mais um momento de confirmação do realinhamento.

Singer define o reformismo forte como um conjunto de "medidas para provocar rápida contração do fosso social, mesmo que ao preço de haver confronto político" e que 
conforma o núcleo da "perspectiva original do PT" que perdurou "nas propostas do partido até 2001" (2012: 186-187). Para ele, o lulismo adotou o "reformismo forte" petista, "porém em versão homeopática, diluídas em alta dose de excipiente, para não causar confronto" (2012: 189). Há uma dimensão conservadora nesse processo, pois o /ulismo só manteve "das propostas originais do PT aquilo que não implicava enfrentar o capital", abandonando propostas tais como "a tributação das fortunas, revisão das privatizações, redução da jornada de trabalho, desapropriação de latifúndios ou negociação dos preços por meio dos fóruns das cadeias produtivas" (2012: 192).

É nesse caráter conservador que incide o tema da arbitragem dos conflitos na análise de Singer. Os governos lulistas, "sustentados pelo subproletariado, buscam equilibrar as classes fundamentais - proletariado e capitalistas - pois o seu sucesso depende de que nenhuma delas tenha força para impor seus próprios desígnios" (2012: 200): o reformismo forte dos trabalhadores ou o neoliberalismo das elites. Daí emerge a importância de Lula pois:

O sucesso das soluções arbitrais, depende, em alguma medida, da figura providencial do líder que dá a cada um o seu quinhão. $O$ reforço da autoridade do presidente, que aparece como 'benfeitor patriarcal' de todas as classes, é parte constitutiva do esquema, e o êxito da arbitragem tira a centralidade da luta de classes. Há, portanto, um componente bonapartista ou cesarista nesse tipo de configuração. (2012: 201).

Este é o cerne da crítica feita ao /ulismo pelo campo vinculado ao paradigma populista. Singer, contudo, opta por analisar os sentidos múltiplos e contraditórios do lulismo e não por condenar o fenômeno como "traição". Gramsci opera da mesma maneira quando elabora sobre o cesarismo, entendendo que esse tipo de fenômeno político "não quer dizer estagnação do quadro. Representa progresso ou retrocesso, a depender do lado para o qual penda a arbitragem. Pode significar avanços (...) ou recuos qualitativos, ou até dar prosseguimento ao curso 'normal' dos acontecimentos" (2002: 201). O lulismo, portanto, significa avanços uma vez que é "um ciclo reformista de redução da pobreza e da desigualdade", ainda que tais avanços sejam menores do que o petismo desejava pois tratase de "um ciclo lento, levando-se em consideração que a pobreza e a desigualdade eram e continuam sendo imensas no Brasil" (2012: 195).

Ademais, o conflito não desparece com o lulismo, mas se reconfigura através da gramática "ricos versus pobres" e não mais pela identidade classista dos anos 1980. Para Singer, "a polarização entre esquerda e direita esmaeceu, sendo substituída por uma polarização entre ricos e pobres, parecida com a do período populista" (2012: 34).

Singer, todavia, se distancia do paradigma populista quando elabora a bela imagem do lulismo como "resolução do que poderíamos chamar de a nossa questão setentrional" (2010: 40). A referência é o famoso artigo escrito por Gramsci em 1926 (antes de ser preso pelo fascismo) denominado "Alguns temas da Questão Meridional". Naquele texto, Gramsci identifica no campesinato do sul da Itália o elemento chave a ser enfrentado pelo proletariado italiano em sua luta para derrotar a burguesia do norte da Itália. Esta formava um bloco histórico com os latifundiários sulistas e cuja base de massas era o camponês pobre do sul. O proletariado precisava conquistar "o consenso das amplas massas camponesas" para ser classe dirigente.

Afirmamos então, partindo do argumento de Singer, que o /ulismo produziu mais do que um realinhamento eleitoral, ou melhor dizendo, que um realinhamento eleitoral desse tipo que ultrapassa o momento das urnas, implicando mesmo em uma mudança dos 
padrões seculares de constituição da hegemonia dominante no Brasil. Assim, com o lulismo, pela primeira vez em nossa história, a massa de pobres, sobretudo do Nordeste, se desligou do bloco histórico dominante. $\mathrm{E}$ isso só foi possível pelo novo terreno político criado pela Constituição Cidadã, com sua gramática de direitos e com as várias possibilidades de enraizamento da cidadania abertas pelo petismo, das quais o lulismo representa um dos caminhos possíveis, absorvendo em síntese várias dessas dinâmicas e deixando outras de lado. A imagem do "sonho rooseveltiano" (2012: 125) é o modo como Singer deu liga a esse acúmulo de direitos, lutas e instituições.

Em 2010, Dilma Rousseff é eleita presidenta e o lulismo enfrenta o desafio de continuar sem ter Lula na direção do processo. Singer apresenta então outra imagem, a do ensaio desenvolvimentista (2016:26). Seu objetivo era, por um lado, reforçar o sentido geral antineoliberal do governo Dilma, em especial com a chamada nova matriz econômica iniciada em 2011; e, por outro, deixar a porta aberta para um outro tipo de interpretação na medida em que as contradições do governo se desenvolvessem positiva ou negativamente: "é aceitável que, no futuro (...), se conclua que a nova matriz não foi assim tão desenvolvimentista. Ficamos, todavia, protegidos pelo vocábulo 'ensaio' que remete tanto ao caráter efêmero da experiência quanto ao seu caráter vago" (Idem).

Em Contradições do Lulismo (2016), o ponto central é marcar a diferença entre a estratégia conciliadora de Lula e a postura de Dilma de "entrar em combate com frações de classe poderosas e resistentes" (2016: 33). Para Singer, Dilma obteve um sucesso inicial até 2012, (auge eleitoral do lulismo nos municípios), mas sofre um recuo significativo a partir de abril de 2013, quando o Banco Central retoma o pilar neoliberal do aumento dos juros para combater a inflação. (2016: 38). Em seguida ocorrem as jornadas de junho, com seu "caráter contraditório" (2016: 39), o qual analisaremos mais adiante, mas que revelam a conclusão de Singer: Dilma não percebeu que, diante dos muitos enfrentamentos que ela abriu com o capital, "precisaria de um forte apoio social" (2016: 51). Ele conclui que a presidente, possivelmente, viveu:

Uma ilusão de ótica semelhante a que engolfou o nacionalismo dos anos 1950/1960. Ao atender os reclamos da burguesia industrial, imaginou que teria seu respaldo no momento em que os grupos contrariados reagissem. $\mathrm{Na}$ hora $\mathrm{H}$, contudo, foi por ela abandonada. $\mathrm{O}$ desconhecimento prático de ensinamentos antigos teria feito com que, como em 1964, as camadas populares não tenham sido mobilizadas para defender a nova matriz quando a burguesia abandonasse o barco" (2016: 54)

Singer passa a operar uma aproximação entre a conjuntura atual e o período dito populista (1945-1964) que é problemática em dois sentidos: primeiro, há toda uma historiografia que rejeita a tese de que o golpe de 1964 ocorreu por falta mobilização das camadas populares; segundo, porque se afasta da análise dos processos contraditórios do lulismo em favor de uma perspectiva mais fechada do processo histórico, na qual "os ensinamentos antigos" resolveriam a ação no presente.

Em 2018, com O Lulismo em Crise, essa tensão se resolve em favor do olhar comparativo com a democracia de 1945 a 1964 pela chave negativa do populismo, embora a análise mantenha pontos de continuidade com a visão aberta de 2012. Um destes pontos de continuidade aparece, por exemplo, quando Singer afirma que "o lulismo é, portanto, profundamente contraditório", mas na sequência impera o olhar mais fechado sobre o fenômeno, quando ele afirma que o lulismo "se presta a inúmeros gêneros de mistificação por ser regressivo e progressivo ao mesmo tempo" (2018: 18, grifo do autor). 
Josué Medeiros

Não é menos importante que a referência teórica principal do autor deixa de ser Gramsci, embora ele ainda se faça presente, para dar lugar a um certo Marx e um certo marxismo, a partir de categorias tais como "classe em si" e "classe para si", e da diferenciação entre "classe" e "massa" já amplamente criticadas pelo caráter determinista ver, principalmente, a obra de Thompson (2008). Se, em 2012, Singer valorizava a repolarização entre pobres e ricos, em 2018 ele diz que a categoria pobre leva ao "obscurecimento" e a "enxergar de maneira enviesada" (2018: 19) os conflitos de classe.

A derrota do lulismo, portanto, é fruto "das suas contradições", que "são igualmente as contradições brasileiras", das quais o /ulismo é "vitima" (2018: 21). São termos que deixam transparecer um fatalismo histórico e estruturalista:

A consequência política é que o setor moderno é grande o suficiente para impor vetos sobre a mudança do sistema, pois, se parte da sociedade está no atraso, parte significativa está no moderno. Por mais paradoxal que pareça, o que paralisa o avanço não é o atraso, é o tamanho do setor modernizado (2018: 22)

Quando Singer analisa a crise do lulismo não com base em esquemas teóricos, mas na fina teia dos eventos e conflitos concretos, sua reflexão reestabelece os pontos de continuidade com os Sentidos do Lulismo. Destacamos dois momentos importantes para pensarmos nossa crise democrática. O primeiro é o papel do sistema partidário nas crises dos anos 1950/1960 e na atual. Para ele, "os três maiores partidos 'reais' desde 1945, quando o Brasil passa a ser uma democracia de massas, até 2016, de um certo ponto de vista são os mesmos, embora os nomes tenham mudado". Há o partido popular (PTB antes e o PT agora) que polariza com o partido de classe média (UDN antes e o PSDB agora). E há o partido do interior (PSD antes e PMDB agora) que estabiliza a disputa. O problema é que "a dificuldade do partido de classe média vencer as eleições presidenciais, uma vez ocorrido o realinhamento eleitoral, estimula o golpismo, estabelecendo uma dinâmica radicalizada, a expensas do desejo do partido popular". (2018: 23-24). Nos anos 1960, o PSD tentou estabilizar o quadro apoiando a posse de Jango. Já o PMDB liderou o projeto cujo objetivo foi "não só revogar a integração obtida pelo lulismo como salgar a terra na qual ela havia crescido: a Constituição de 1988" (2018: 13).

O segundo aparece na síntese que Singer faz das jornadas de junho de 2013, captando seus sentidos contraditórios e que decorrem da situação em que, "no Brasil, as posições reformistas fracas como o lulismo têm um conteúdo perigoso" pois, embora não ameacem o sistema, afetam seu modo de funcionamento, com perdas concretas para os que dominam: "de maneira muito contraditória, os acontecimentos de junho de 2013, em sua vertente de esquerda, apontavam na direção antimercantil" e é por isso que, para Singer, as jornadas ativaram "no sentido oposto, energias destinadas a desfazer - via congelamento de gastos públicos, terceirização e reforma trabalhista - os avanços obtidos na década lulista (2018: 24). Essa análise nos permite fugir tanto da culpabilização das mobilizações pelos eventos posteriores quanto da positivação unilateral daquelas lutas. 0 ponto central é que sem os processos virtuosos do lulismo, aquelas manifestações não seriam possíveis. E é justamente por isso que cabia ao PT e aos movimentos sociais do seu campo dar consequência positiva aos sentidos antimercantis de junho de 2013, em vez de ficarem presos à defesa do governo e, no limite, do sistema político como um todo.

Do nosso ponto de vista, entendemos que as eleições de 2014 confirmam que a história ainda estava aberta e que escolhas políticas diferentes estavam disponíveis tanto para o lulismo e o petismo quanto para as elites. Dilma vence as eleições em 2014 com o 
Josué Medeiros

programa mais à esquerda de todas as vitórias do PT, com sentido de aprofundar os direitos e a cidadania presentes na Carta de 1988. Foi a não sustentação daquele programa que desarmou os setores progressistas para compreender e agir em um cenário político internacional de desdemocratização e crescimento da extrema-direita no Ocidente e em um quadro nacional no qual se firma uma ampla unidade das elites em torno da proposta de interditar o /ulismo e cancelar o pacto de 1988 da democracia brasileira.

\section{Considerações finais}

Este artigo buscou analisar o fenômeno do /ulismo em sua relação estrutural com a Constituição de 1988 e com o que chamamos de petismo (coletividade de lutas e movimentos que constituiu o PT) de modo a contribuir com as interpretações sobre a crise da democracia brasileira. Partimos do pressuposto de que esta noção, quando aplicada sem mediações à realidade nacional, se mostra insuficiente para explicar o que se propõe.

Nessas considerações finais, para além das mediações que apresentamos ao longo do texto, faz-se necessário avançar para a conjuntura atual da pandemia da Covid-19 e do bolsonarismo no governo. Para essa tarefa vamos nos apoiar nas formulações da filósofa política Wendy Brown em seu livro Nas Ruínas do Neoliberalismo, as quais podem nos ajudar a avançar um pouco mais no entendimento do quadro global e brasileiro.

Vivemos uma conjuntura de crise sanitária e econômica sem precedentes. Bolsonaro sabotou todas as ações que poderiam ter reduzido as dores humanas da pandemia com suas mais de 300 mil mortes. Ademais, vivemos uma tragédia de 14 milhões de desempregados, retorno da fome e promessa de mais violência.

A violência é o principal motor do bolsonarismo: violência social do neoliberalismo radicalizado, que desfaz os laços sociais; e violência política contra a Constituição de 1988, posto que ela tem um sentido de reforçar os direitos e a solidariedade. Nossa Carta Cidadã afirma um pertencimento universal à cidadania, embora seja óbvio que não o efetiva plenamente. O bolsonarismo busca organizar um pertencimento de novo tipo, privado, particular, miliciano, do "nós contra eles".

Não se trata de um processo exclusivamente brasileiro. Ao contrário, seu epicentro vem sendo os Estados Unidos desde 2016, quando Donald Trump ganhou a presidência daquela nação. Em seu mandato, o agora ex-presidente Trump estimulou abertamente um processo idêntico de "nós contra eles". Destacamos, durante a vigência da pandemia, o estímulo institucional à violência social e institucional, quando Trump enviou tropas federais para reprimir manifestantes antirracistas sem autorização dos governos estaduais, e conclamou os movimentos supremacistas brancos a ir para as ruas enfrentar os ativistas do Black Lives Matter. E, finalmente, quando contestou o resultado das eleições em que foi derrotado e apoiando movimentos golpistas contra a da vitória de Joe Biden.

A imagem do "nós contra eles" é usada em par com a categoria de populismo, termo que supostamente serve para falar de Lula e de Bolsonaro, de Trump e de Chávez, de Perón e de Putin, de Erdogan e de Vargas, alcançando todo o planeta e diversos tempos históricos. Ficamos, desta maneira, presos em um movimento circular, tal qual o descrito por Brown: "indignação, moralização, sátira e esperanças vãs de que facções internas ou escândalos na direita produzirão sua autodestruição têm prevalecido sobre estratégias sérias para desafiar essas forças por meio de alternativas convincentes" (2019: 10). 
A saída proposta por ela é caracterizar esta extrema-direita como neoliberalismo antidemocrático. Para Brown, trata-se de uma:

\begin{abstract}
Combinação incomum entre elementos típicos do neoliberalismo (favorecimento do capital, repressão do trabalho, demonização do Estado social e político e exaltação da liberdade) com seus aparentes opostos (nacionalismo, imposição da moralidade tradicional, antielitismo populista e demandas por soluções estatais para problemas econômicos e sociais) (Idem).
\end{abstract}

Brown argumenta que esse processo resulta de três dinâmicas fundamentais do neoliberalismo: "a demonização do social e do político" (2019: 16-17), o que é "fundamental para gerar uma cultura antidemocrática desde baixo, ao mesmo tempo em que constrói e legitima formas antidemocráticas de poder estatal desde cima" (2019: 39). Isso se completa com a mobilização da moral ocidental, cristã, masculina e branca para criar os laços desta coletividade sem necessitar das dimensões do social e do político.

A análise de Brown sobre o neoliberalismo antidemocrático pode nos servir para entender a política brasileira contemporânea de um modo mais aprofundado do que é possível com as categorias de populismo ou crise da democracia. Para isso, é preciso traduzir o que ela analisa sobre os EUA para o Brasil, retomando o fio metodológico inicial de adaptar as categorias analíticas do centro do capitalismo para países periféricos.

Neste artigo, buscamos contribuir com esse esforço interpretativo afirmando o golpe de 2016 e o bolsonarismo como os momentos constitutivos do nosso neoliberalismo antidemocrático. Para isso, foi fundamental interditar o lulismo, fenômeno que, em suas contradições, buscou enraizar os direitos inscritos na Constituição de 88.

Não é por outra razão que o lulismo está no centro de uma possível reversão deste processo, caso o ex-presidente Lula possa ser candidato em 2022. Contudo, será preciso ir além dos sentidos contraditórios do Iulismo em tripla chave: primeiro, recuperando dinâmicas democráticas do petismo que foram abandonadas pelos governos Lula e Dilma; segundo, atualizando lutas e processos com as energias contemporâneas do novo mundo do trabalho - com a interseccionalidade entre classe, gênero e raça - e de novos temas centrais como a emergência climática; terceiro, elaborando novas soluções para os problemas da fome e do desemprego que ressurgem e para os quais as fórmulas consagradas do lulismo não serão suficientes.

(Recebido para publicação em setembro de 2020)

(Reapresentado em setembro de 2020)

(Aprovado para publicação em dezembro de 2020)

\title{
Cite este artigo
}

MEDEIROS, Josué, 2020. O significado do lulismo na vida política brasileira: direitos e institucionalização das lutas à luz da Constituição de 88. Revista Estudos Políticos: a publicação semestral do Laboratório de Estudos Hum(e)anos (UFF). Rio de Janeiro, Vol.11 | N.22, pp. 160188, dezembro de 2020. 


\section{NOTAS}

1. Dados fornecidos pelo departamento de estatística da entidade.

\section{Referências Bibliográficas}

ANDERSON, Perry. "O Brasil de Lula". Novos Estudos CEBRAP, (91), 2011, 23-52.

ANTUNES, Ricardo. A esquerda fora do lugar: O Governo Lula e os descaminhos do PT. Campinas, Editora Autores Associados. 2006

ANTUNES, Ricardo. "O Brasil da Era Lula". In: Margem Esquerda, n 16. São Paulo: Ed Boitempo, 2011.

AVRITZER, Leonardo. "Sociedade Civil e Participação no Brasil Democrático". In: MELO, Carlos \& Saez, Manuel (orgs). Democracia Brasileira: Balanço e perspectivas para o século XXI. Belo Horizonte. Ed. UFMG. 2007

BEZERRA, Carla. Do poder popular ao modo petista de governar. Dissertação de Mestrado. São Paulo: USP, 2014

BRANDÃO, Gildo Marçal. A esquerda positiva: as duas almas do Partido Comunista - 1920/1964. São Paulo: HUCITEC, 1997.

BRANDÃO, Gildo Marçal. Linhagens do Pensamento Político Brasileiro. 2 Edição. São Paulo: Editora Hucitec. 2007.

BRANDÃO, Gildo Marçal. "O significado do prestismo na política brasileira". In: COELHO, Simone de Castro Tavares (org). Gildo Marçal Brandão: itinerários intelectuais. São Paulo: Ed. Hucitec, 2010.

BROWN, Wendy. Nas ruínas do neoliberalismo: a ascensão da política antidemocrática no ocidente. São Paulo: Ed. Politeia, 2019.

CARDOSO, Adalberto. A década Neoliberal e a crise dos sindicatos no Brasil. São Paulo. Boitempo, 2003.

CARVALHO, José Murilo de. Cidadania no Brasil. O longo Caminho. Rio de Janeiro: Civilização Brasileira, 2001. 
CARVALHO, José Murilo de. A construção da ordem: a elite política imperial. Brasília: Editora Universidade de Brasília, 2003.

CONCEIÇÃO, Jefferson. "ABC: a região em mudança". Teoria e Debate, Edição 37. 1998.

COMPARATO, Fábio. Muda brasil: uma constituição para o desenvolvimento democratico. Imprenta: São Paulo, Brasiliense, 1986.

COUTINHO, Carlos Nelson. "Comentário". In: GARCIA, Marco Aurélio (org). As esquerdas e a Democracia. Rio de Janeiro: Paz e Terra. CEDEC, 1986.

DAGNINO, Evelina. "Os movimentos sociais e a emergência de uma nova noção de cidadania". DAGNINO, Evelina (org). Os anos 90: Política e Sociedade no Brasil. São Paulo: Ed. Brasiliense, 2004.

GARCIA, Marco Aurélio. (org). As esquerdas e a Democracia. Rio de Janeiro: Paz e Terra. CEDEC, 1986.

GIANNOTTI, Vito. História das lutas dos trabalhadores no Brasil. Rio de Janeiro: Mauad X, 2007.

GRAMSCI, Antonio. Cadernos do cárcere Rio de Janeiro, Brasil: Civilização Brasileira, 2002.

FERNANDES, Florestan. "A Constituição de 1988: conciliação ou ruptura". In: Florestan Fernandes na Constituinte: leituras para a reforma política. São Paulo: Ed. FPA e Expressão Popular, 2014.

FONTES, Paulo. Um nordeste em São Paulo: trabalhadores migrantes em São Miguel Paulista (1945-1966). Rio de Janeiro, Editora FGV, 2008.

FORTES, Alexandre. "Reflexões sobre o lugar do PT na história da esquerda brasileira". In: Histórias e Perspectivas da Esquerda. Fortes, Alexandre (org). São Paulo: Editora Fundação Perseu Abramo, 2005.

LEAL, Murilo. LEAL, Murilo. A Reinvenção da classe trabalhadora (1953-1964). Campinas: Editora da Unicamp, 2011.

LEVITSKY, Steven.; ZIBLATT, Daniel. Como as democracias morrem. Rio de Janeiro: Ed. Zahar, 2019. 
MARTINS, Heloísa de Souza \& RODRIGUES, Iram Jácome. "O sindicalismo brasileiro na segunda metade dos anos 90." Tempo Social; Rev. Sociol. USP, S. Paulo, 11(2): 155182, out. 1999

MEDEIROS, Josué. Para além do lulismo: o fazer-se do petismo na política brasileira. 297f. Tese (Doutorado em Ciência Política) - Instituto de Estudos Sociais e Políticos, Universidade do Estado do Rio de Janeiro, 2016.

MOUNK, Yascha. O povo contra a democracia: por que nossa liberdade corre perigo e como salvá-la. Companhia das Letras: São Paulo, 2018.

MÜLLER, Jan-Werner. What Is Populism?. University of Pennsylvania Press, 2016.

NETO, Sebastião e GIANNOTTI, Vito. CUT por dentro e por fora. Petrópolis: Vozes, 1990

NETO, Sebastião e GIANNOTTI, Vito. CUT, ontem e hoje. São Paulo, S.P.: Editora Página Aberta LTDA, 1991.

OLIVEIRA, Francisco. "Privatização do Público, Destituição da Fala e Anulação da Política: o Totalitarismo Neoliberal". DE OLIVEIRA, Francisco; PAOLI, Maria Célia Pinheiro Machado (Ed.). Os sentidos da democracia: políticas do dissenso e hegemonia global. Vozes, 1999.

OLIVEIRA, Francisco; PAOLI, Maria Célia; REZEK, Cibele. "Orçamento Participativo: uma invenção da política". In: BENEVIDES, Maria Vitória; KERCHE, Fábio; VANNUCHI, Paulo (orgs). Reforma Política e Cidadania. São Paulo: Ed. FPA, 2003.

PARTIDO DOS TRABALHADORES. Resoluções de Encontros e Congressos (1979-1998). São Paulo: Fundação Perseu Abramo, 1998.

PILATTI, Adriano. A Constituinte de 1987-1988:

progressistas, conservadores, ordem econômica e regras do jogo. Editora PUC-Rio, 2008.

RODRIGUES, Iram Jácome; ARBIX, Glauco. "Novas Estratégias Sindicais Diante do Desemprego". São Paulo em Perspectiva, São Paulo, v. 10, n. 1, 1996, p. 77 a 86

REIS, Fábio Wanderley. "Engenharia e decantação". In: BENEVIDES, Maria Vitória; KERCHE, Fábio; VANNUCHI, 
Paulo (orgs). Reforma Política e Cidadania. São Paulo: Ed. FPA, 2003.

RUNCIMANN, David. Como a democracia chega ao fim. São Paulo: Todavia, 2018.

SADER, Emir, "Brasil: de Getúlio a Lula". In: SADER, Emir e GARCIA, Marco Aurélio. Brasil: entre o passado e o futuro. São Paulo: Ed. Boitempo/Perseu Abramo, 2010.

SAMUELS, David. "As bases do petismo." OPINIÃO PÚBLICA, Campinas, Vol. X, no 2, Outubro, 2004.

SAMUELS, David. "A evolução do petismo" (2002-2008). OPINIÃO PÚBLICA, Campinas, vol. 14, no 2, Novembro, 2008, p.302-318.

SAMUELS, David, \& ZUCCO, Cesar Jr. (2014), "Lulismo, Petismo, and the Future of Brazilian Politics" in: Journal of Politics in Latin America, 6, 3, 129-158.

SANTOS, Boaventura de Souza (org.). Democratizar a democracia: os caminhos da democracia participativa. Rio de Janeiro: Civilização Brasileira, 2002.

SANTOS, Wanderley Guilherme. "Paradigma e história: a ordem burguesa na imaginação social brasileira". In: Roteiro Bibliográfico do Pensamento Político-Social Brasileiro (1870-1965). Belo Horizonte: Ed. UFMG, 2002.

SANTOS, Wanderley Guilherme. A democracia impedida: O Brasil no século XXI. Rio de Janeiro: Ed FGV, 2017

SCHWARZ, Roberto. "Um seminário de Marx". In: Sequências brasileiras. São Paulo, Companhia das Letras.

SCHWARCZ, Lilian; STARLING, Heloisa. Brasil: uma biografia, São Paulo: Companhia das Letras, 2015.

SINGER, André. Os Sentidos do Lulismo: reforma gradual e pacto conservador. São Paulo: Cia das Letras, 2012.

SINGER, André. O lulismo em crise: um quebra cabeça do período Dilma. São Paulo: Cia das Letras, 2018

SINGER, André e LOUREIRO, Isabel (orgs). As contradições do lulismo: a que ponto chegamos? São Paulo: Ed. Boitempo, 2016. 
TELES, Vera da Silva. "Sociedade civil e a construção de espaços públicos". DAGNINO, Evelina (org). Os anos 90: Política e Sociedade no Brasil. São Paulo: Brasiliense, 2004.

THOMPSON, Edward Palmer. Formação da Classe Operária Inglesa. São Paulo: Paz e Terra. 1987.

VIANNA, Luiz Werneck. "O ocidente incompleto do PCB". In: A transição: da Constituinte à sucessão presidencial. Rio de Janeiro: Revan, 1989.

VIANNA, Luiz Werneck. A Revolução Passiva: iberismo e americanismo no Brasil. Rio de Janeiro: Revan, 1997.

WHITAKER, Francisco (org). Cidadão Constituinte - a saga das emendas populares. São Paulo, Editora Paz e Terra, 1989. 